INTERNATIONAL JOURNAL OF RESEARCHES IN BIOSCIENCES, AGRICULTURE AND TECHNOLOGY (C) VISHWASHANTI MULTIPURPOSE SOCIETY (Global Peace Multipurpose Society) R. No. MH-659/13(N) www.vmsindia.org

\title{
REMOVAL OF HEAVY METAL IONS BY ADSORPTION TECHNIQUE USING ADSORBENT PREPARED FROM WASTE MATERIAL
}

\author{
M. P. Patil \\ Department of Chemistry, Sevadal Mahila Mahavidyalaya, Nagpur \\ E-mail: patilmanjusha67@gmail.com
}

\begin{abstract}
:
Water pollution is a now a serious problem due to discharge from industrial waste, agricultural waste into water sources. Various physicochemical and biological methods have been studied for metal ion removal. Amongst various techniques adsorption is the easy and cheaper method for removal of heavy metal ions. In the present work adsorbent prepared from waste material like peanut shells which are easily available used for the preparation of adsorbent. It was observed that the adsorbent prepared from waste peanut shells can act as a good adsorbent.
\end{abstract}

Keywords: Adsorption, peanut shells, Photocalorimetric technique.

\section{INTRODUCTION:}

In recent years the problem of colour removal from waste water has been considered to be of great importance because of the need to satisfy increasing demand for water for various uses. Treatment processes for the removal of heavy metal ions from waste water include coagulation, carbon adsorption, ion exchange, precipitation; reverse osmosis etc. Adsorption is one of the techniques used for removal of heavy metal ions. The preparation of activated carbon from waste material could increase economic return and also provides an excellent method for solid waste disposal thereby reducing pollution.

Many toxic metals have been discharged to the environment through natural phenomenon and human activities such as industrial waste wastes, agricultural particles transport and waste disposal causing serious water pollution. Heavy metals are well known for toxicity and their disposal is a significant industrial waste problem. Cadmium and chromium show high toxicity to humans as well as to animals. All these metals are also toxic to plants, being cadmium the strongest phototoxic elements. We have used agro waste material as low cost adsorbent the basic components of the agricultural waste materials include hemicelluloses, lignin. Lipids, proteins, simple sugars, water, hydrocarbons and starch containing variety of functional groups. In particular agricultural materials containing cellulose show a potential sorption capacity for various pollutants. If these wastes could be used a low- cost adsorbents, it will provide a two advantages to environmental pollution. It reduces volume of waste materials and secondly the low cost adsorbent prepared from it can reduce the treatment of waste water at reasonable cost. Agricultural activated carbon production is good due to its low ash content and reasonable hardness.

\section{MATERIAL AND METHODS:}

The waste peels were collected, washed several times with water then dried till the moisture is completely removed. Fine powder was prepared. Activated charcoal from powder of peanut shells was prepared by carbonisation and activation by $\mathrm{CaCl}_{2}$. Photocalorimetric Technique is used for study.

Photocalorimetric Technique

Photocalorimetric Technique is used for determination of colour. The intensity of colour of the substance is directly proportional to its concentration. The solutions of different concentrations were prepared. By adding activated charcoal in a solution of chromium and nickel shaking for 15 minutes after filtration optical density and $\mathrm{pH}$ of the solution was recorded. Concentration of unknown solution can be determined as follows.

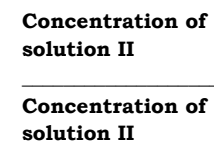

\section{RESULT \& DISCUSSION:}

In case of nickel solution the optical density and colour of the solution is found to be decreased after adsorption. The $\mathrm{pH}$ of the solution changes from 3.55 to 5.59 before adsorption with decreasing concentration of solution. After adsorption the change in $\mathrm{pH}$ was found to be changing from 7.42 to 8.16. According to 
experimental analysis the adsorption of nickel is not found at very low concentrations.

In case of chromium solution the optical density and colour of the solution is found to be decreased after adsorption. The $\mathrm{pH}$ of the solution changes from 3.30 to 4.04 before adsorption with decreasing concentration of solution. After adsorption the change in $\mathrm{pH}$ was found to be changing from 5.05 to 7.41 . Thus the adsorbent prepared from peanut shells can act as a good adsorbent.

\section{REFEENCES:}

Abolino, O., Aceto, M., Malandrino, M., Sarzanini, C. and Menntasti, E. (2003): Water Res, Pp.37, 1619.

Ahmedna, M., Marshall, W.E., Rao, R. M. (2000): Production of granular activated carbon from selected agricultural by-products and evaluation of their physical, chemical and adsorption properties. Bioresour. Technol. 71:113-123.
Ayuso, E.A., Sanchez, A. G. and Querol, X. (2003): Water Res, Pp.37, 4855.

Bailey, S. E., Olin, T. J., Bricka, R. M. and Adrian D. D. (1999): A Review of potentially Low-Cost Sorbents for Heavy Metals. Water Res.33(11), Pp.2409, 2479.

Gode, E. and Pehlivan, (2007): Bioresour. Tech. Pp.98, 904

Ingleezakis, V.J., Zorpas, A. A., Loizidou, M.D. and Griropaulou, H. P. (2003): Microper Mesoper Water Res, Pp.37, 1619.

Johns, M. M., Marshall, W. E. and Toles, C. A. (1998): "Agricultural By-Products granular Activated Carbons for adsorbing Dissolved Metals and Organics”, J. Chem. technol. Biotechnol. Pp.71; 131-140.

Lin, S. H., and Junag, R. S. (2002): J. Hazard Matter, Pp. 315, 892.

Zaglezakis, V. J., Loizidou, M. D. and Griropaulou, H.P. (2003): Microper Mesoper Master, Pp.61, 167.

Table 1- Determination of optical density of $\mathrm{Ni}^{+2}$ solutions before and after adsorption

\begin{tabular}{|l|l|l|l|l|l|l|l|l|l|l|}
\hline Initial conc. & \multicolumn{2}{|c|}{$\mathbf{1 x 1 0}^{-\mathbf{1}}$} & \multicolumn{2}{|c|}{$\mathbf{5 x 1 0}^{-\mathbf{2}}$} & \multicolumn{2}{c|}{$\mathbf{2 . 5 \times 1 0 ^ { - 2 }}$} & \multicolumn{2}{c|}{$\mathbf{1 . 2 5 x}^{-2}$} & \multicolumn{2}{c|}{$\mathbf{0 . 6 x 1 0}^{-2}$} \\
\hline Wavelength & Before & After & Before & After & Before & After & Before & After & Before & After \\
\hline $\mathbf{4 0 0}$ & 0.20 & 0.17 & 0.16 & 0.08 & 0.11 & 0.05 & 0.04 & 0.33 & 0.15 & 0.15 \\
\hline $\mathbf{5 0 0}$ & 0.32 & 0.09 & 0.30 & 0.04 & 0.29 & 0.04 & 0.30 & 0.33 & 0.28 & 0.28 \\
\hline $\mathbf{5 2 0}$ & 0.14 & 0.08 & 1.11 & 0.04 & 0.10 & 0.03 & 0.11 & 0.33 & 0.08 & 0.08 \\
\hline $\mathbf{5 4 0}$ & 0.31 & 0.09 & 0.28 & 0.04 & 0.26 & 0.03 & 0.28 & 0.02 & 0.25 & 0.25 \\
\hline $\mathbf{p H}$ & 3.55 & 7.42 & 3.46 & 7.42 & 3.87 & 7.86 & 4.56 & 7.96 & 5.59 & 8.16 \\
\hline
\end{tabular}

\section{Graph 1 : For adsorption of Nickel}
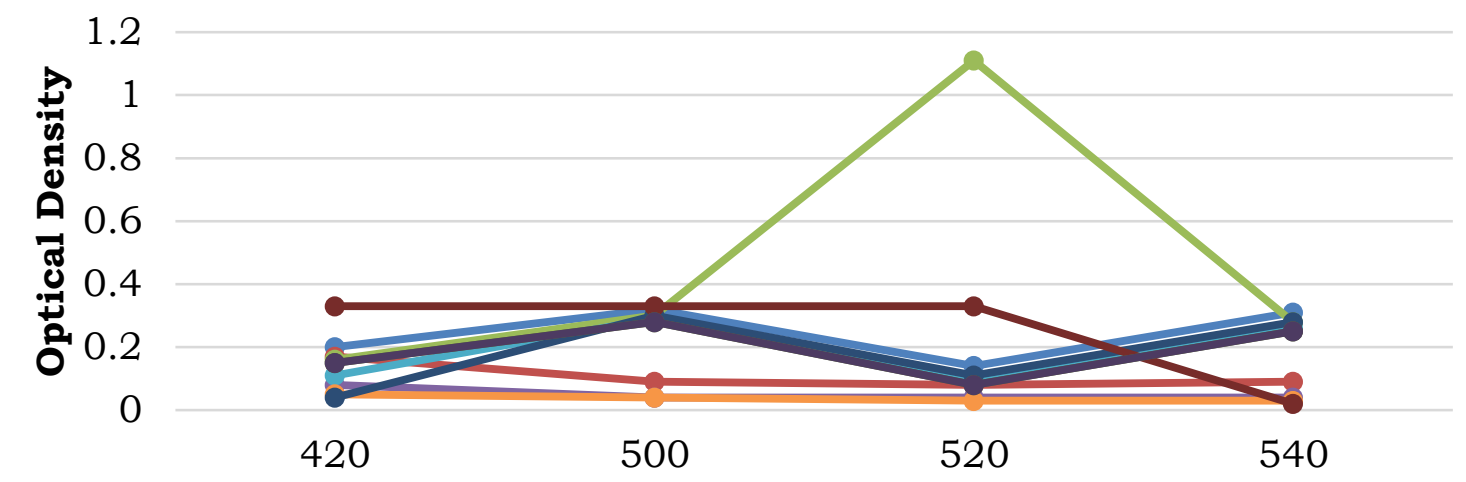

Wavelength

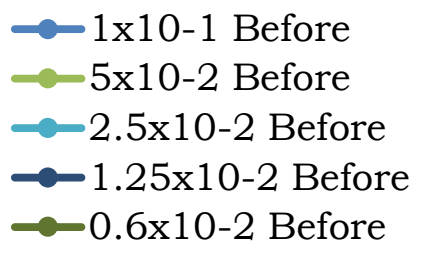

$$
\begin{aligned}
& \multimap 1 \times 10-1 \text { After } \\
& \rightarrow 5 \times 10-2 \text { After } \\
& \multimap-2.5 \times 10-2 \text { After } \\
& \rightarrow-1.25 \times 10-2 \text { After } \\
& \rightarrow 0.6 \times 10-2 \text { After }
\end{aligned}
$$


Table 2 - Determination of concentration of $\mathrm{Ni}^{+2}$ solutions after adsorption

\begin{tabular}{|c|c|c|c|c|c|}
\hline Initial conc. & $1 \times 10^{-1}$ & $5 \times 10^{-2}$ & $2.5 \times 10^{-3}$ & $1.25 \times 10^{-2}$ & $0.6 \times 10^{-2}$ \\
\hline \multicolumn{6}{|l|}{ Wavelength } \\
\hline 420 & 0.085 & 0.025 & 0.011 & 0.009 & 0.006 \\
\hline 500 & 0.028 & 0.006 & 0.003 & 0.001 & 0.006 \\
\hline 520 & 0.057 & 0.018 & 0.007 & 0.003 & 0.006 \\
\hline 540 & 0.029 & 0.007 & 0.002 & 0.0008 & 0.006 \\
\hline pH & 7.42 & 7.42 & 7.86 & 7.96 & 8.16 \\
\hline
\end{tabular}

\section{Graph 2: Determination of concentration of $\mathrm{Ni}+2$ after} adsorption

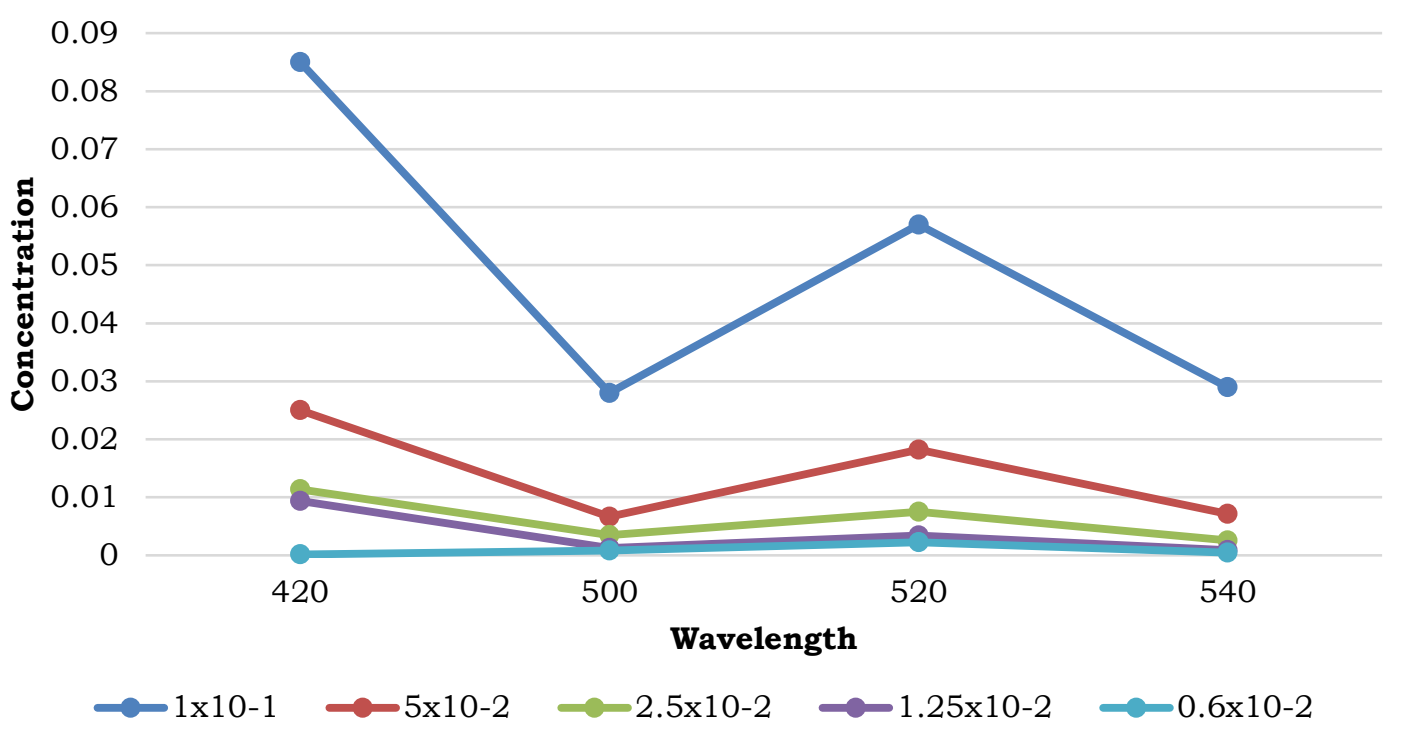

Table 3 - Determination of optical density of $\mathrm{Cr}^{+3}$ solutions before and after adsorption

\begin{tabular}{|l|l|l|l|l|l|l|l|l|l|l|}
\hline Initial conc. & \multicolumn{3}{|l|}{$\mathbf{1 x 1 0}-\mathbf{5 x 1 0 - 2}$} & \multicolumn{2}{|l|}{$\mathbf{2 . 5 x 1 0 - 2}$} & \multicolumn{2}{|l|}{$\mathbf{1 . 2 5 x 1 0 - 2}$} & \multicolumn{2}{|l|}{$\mathbf{0 . 6 \times 1 0 - 2}$} \\
\hline Wavelength & Before & After & Before & After & Before & After & Before & After & Before & After \\
\hline $\mathbf{4 0 0}$ & 0.36 & 0.33 & 0.22 & 0.20 & 0.12 & 0.11 & 0.06 & 0.04 & 0.90 & 0.01 \\
\hline $\mathbf{4 2 0}$ & 0.74 & 0.68 & 0.49 & 0.46 & 0.37 & 0.32 & 0.13 & 0.10 & 1.05 & 0.15 \\
\hline $\mathbf{4 8 0}$ & 1.87 & 1.47 & 0.85 & 0.80 & 0.43 & 0.36 & 0.19 & 0.10 & 0.98 & 0.01 \\
\hline $\mathbf{5 0 0}$ & 1.61 & 1.75 & 1.11 & 1.08 & 0.69 & 0.62 & 0.45 & 0.36 & 1.25 & 0.26 \\
\hline $\mathbf{5 2 0}$ & 1.63 & 1.59 & 0.95 & 0.92 & 0.52 & 0.45 & 0.27 & 0.18 & 1.06 & 0.07 \\
\hline $\mathbf{5 4 0}$ & 1.63 & 1.61 & 1.11 & 1.08 & 0.72 & 0.63 & 0.46 & 0.35 & 1.26 & 0.24 \\
\hline $\mathbf{6 2 0}$ & 0.75 & 0.60 & 0.44 & 0.29 & 0.16 & 0.03 & - & - & 0.70 & 0.10 \\
\hline $\mathbf{6 8 0}$ & 0.64 & 0.28 & 0.43 & 0.30 & 0.22 & 0.13 & 0.08 & 0.23 & 0.94 & 0.13 \\
\hline $\mathbf{p H}$ & 3.70 & 5.05 & 3.73 & 5.51 & 3.82 & 6.20 & 3.93 & 6.62 & 4.04 & 7.41 \\
\hline
\end{tabular}




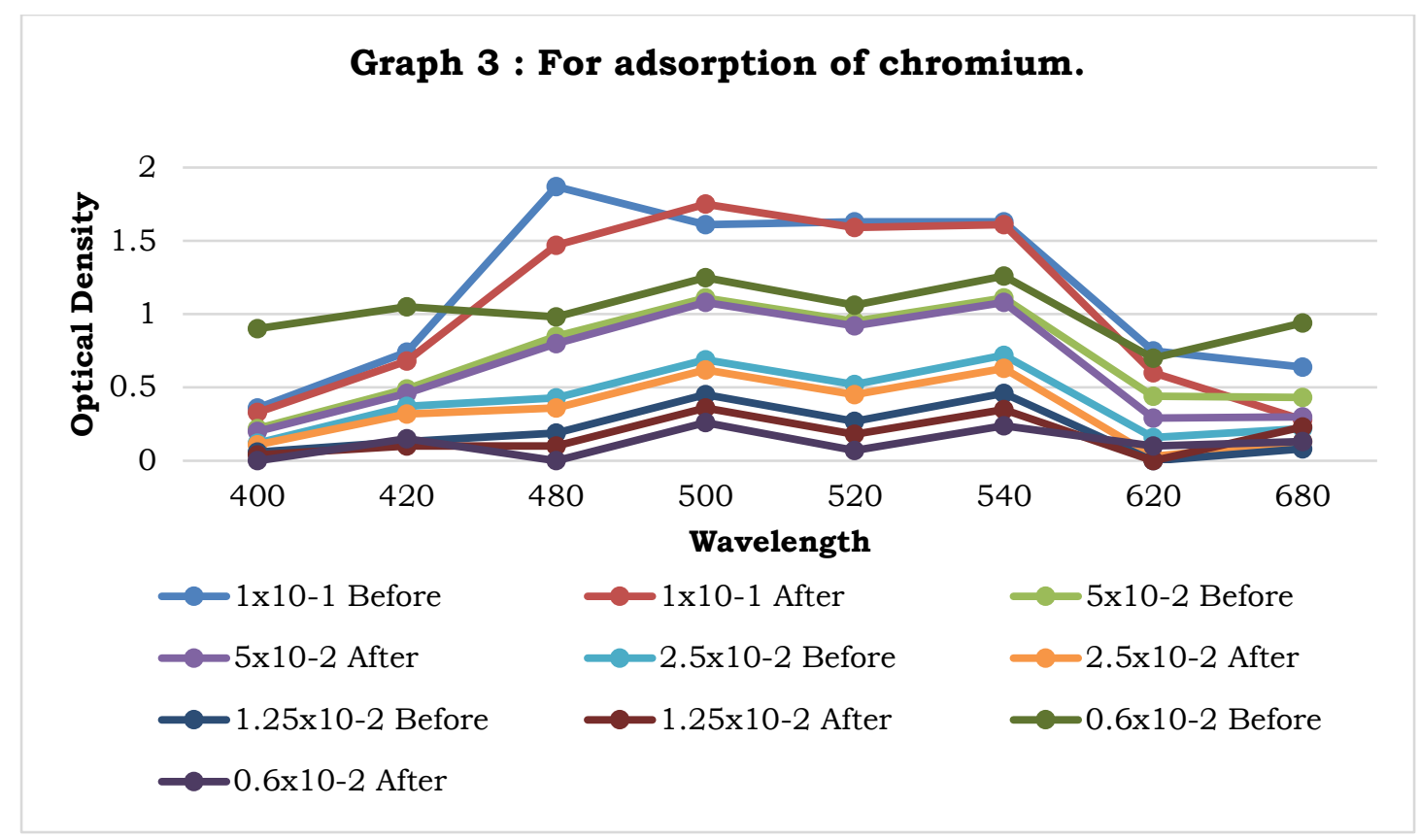

Table 4 - Determination of concentration of $\mathrm{Cr}^{+3}$ solutions after adsorption

\begin{tabular}{|l|l|l|l|l|l|}
\hline Initial conc. & $\mathbf{1 \times 1 0 ^ { - 1 }}$ & $\mathbf{5 \times 1 0 ^ { - 2 }}$ & $\mathbf{2 . 5 \times 1 0 ^ { - 2 }}$ & $\mathbf{1 . 2 5 \times 1 0 ^ { - 2 }}$ & $\mathbf{0 . 6 \times 1 0 ^ { - 2 }}$ \\
\hline Wavelength & & & & & \\
\hline $\mathbf{4 0 0}$ & $9.16 \times 10^{-2}$ & $1.13 \times 10^{-2}$ & $3.0 \times 10^{-3}$ & $7.5 \times 10^{-3}$ & $6.9 \times 10^{-5}$ \\
\hline $\mathbf{4 2 0}$ & $9.18 \times 10^{-2}$ & $4.69 \times 10^{-2}$ & $2.16 \times 10^{-2}$ & $9.6 \times 10^{-3}$ & $8.9 \times 10^{-4}$ \\
\hline $\mathbf{4 8 0}$ & $9.13 \times 10^{-2}$ & $4.70 \times 10^{-2}$ & $1.07 \times 10^{-2}$ & $9.6 \times 10^{-3}$ & $3.8 \times 10^{-4}$ \\
\hline $\mathbf{5 0 0}$ & $9.35 \times 10^{-2}$ & $4.86 \times 10^{-2}$ & $1.72 \times 10^{-2}$ & $3.6 \times 10^{-3}$ & $1.65 \times 10^{-3}$ \\
\hline $\mathbf{5 2 0}$ & $9.75 \times 10^{-2}$ & $4.84 \times 10^{-2}$ & $2.16 \times 10^{-2}$ & $8.3 \times 10^{-3}$ & $8.2 \times 10^{-4}$ \\
\hline $\mathbf{5 4 0}$ & $9.87 \times 10^{-2}$ & $4.86 \times 10^{-2}$ & $2.18 \times 10^{-2}$ & $9.5 \times 10^{-3}$ & $1.53 \times 10^{-3}$ \\
\hline $\mathbf{p H}$ & 5.05 & 5.51 & 6.20 & 6.62 & 7.41 \\
\hline
\end{tabular}

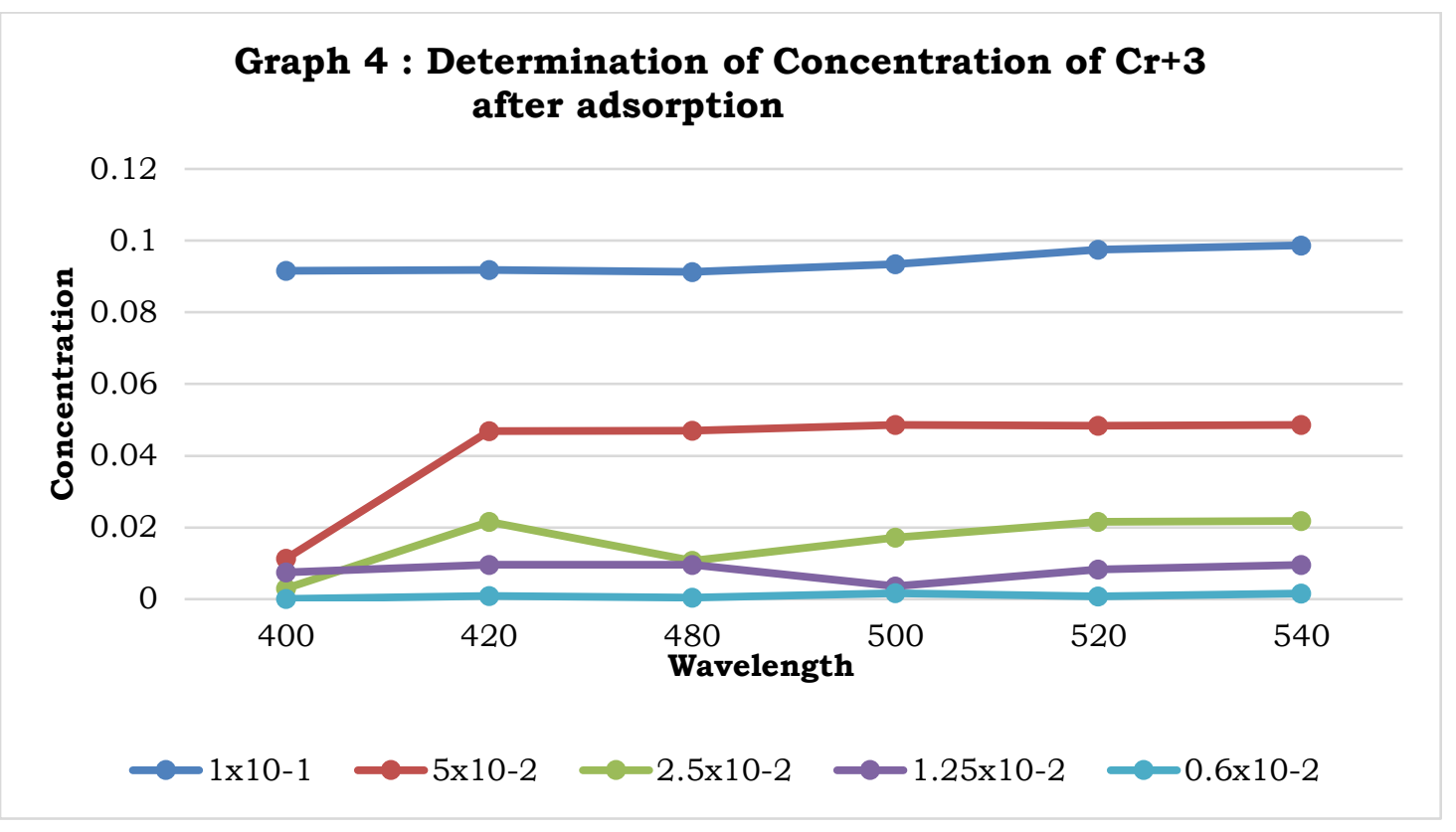

